\title{
PRÁTICAS TERRITORIAIS INDÍGENAS ENTRE A FLEXIBILIDADE E A FIXAÇÃO
}

Michael Kent

\section{Introdução}

No início de maio de 2005, um encontro sob certo aspecto tenso entre autoridades políticas aconteceu nas ilhas dos Uros, um grupo indígena de aproximadamente duas mil pessoas que habita os extensos juncais do Lago Titicaca, no Peru ${ }^{1}$ (ver mapa 1 para as localidades mencionadas no presente artigo). A pauta do encontro era a proliferação galopante de ilhas, resultado de sua frequente separação. O habitat excepcional dos Uros consiste de ilhas artificiais, construídas em plataformas de juncos e suas raízes, que se soltam do fundo do lago durante períodos recorrentes de enchentes. Em função da condição flutuante das ilhas e da sua estrutura física delicada, elas são relativamente fáceis de dividir, fundir ou deslocar pelos juncais. Por exemplo, quando um conflito se instaura numa ilha e as tentativas de mediação falham, a solução mais comum é a separação: com uma grande serra a ilha é cortada em pedaços e cada parte segue seu próprio caminho.

Ao longo dos anos anteriores, o número de ilhas aumentou rapidamentede três para 20 - como decorrência de estratégias econômicas voltadas para a concentração dos benefícios advindos do turismo, a principal fonte de renda dos Uros. Famílias com acesso privilegiado a guias turísticos tinham começado a se separar em ilhas ainda menores, com poucos habitantes, de forma a evitar a dispersão maior dos turistas. Como consequência, desigualdades econômicas cresciam a passos firmes entre os Uros. Para restabelecer uma distribuição mais extensa de recursos do turismo, as autoridades principais dos Uros - incluindo o seu prefeito e o conselho diretivo das ilhas - tentaram forçar a fusão de ilhas flutuantes para gerar unidades maiores. Iniciados em fevereiro de 2005, esses esforços foram amparados por diversas medidas voltadas para a fixação das práticas territoriais, incluindo a proibição da separação de ilhas, o estabelecimento de um número mínimo de famílias por ilha e a criação de um sistema de licenças que fazia com que qualquer mudança 
Mapa 1 - A Baía de Puno

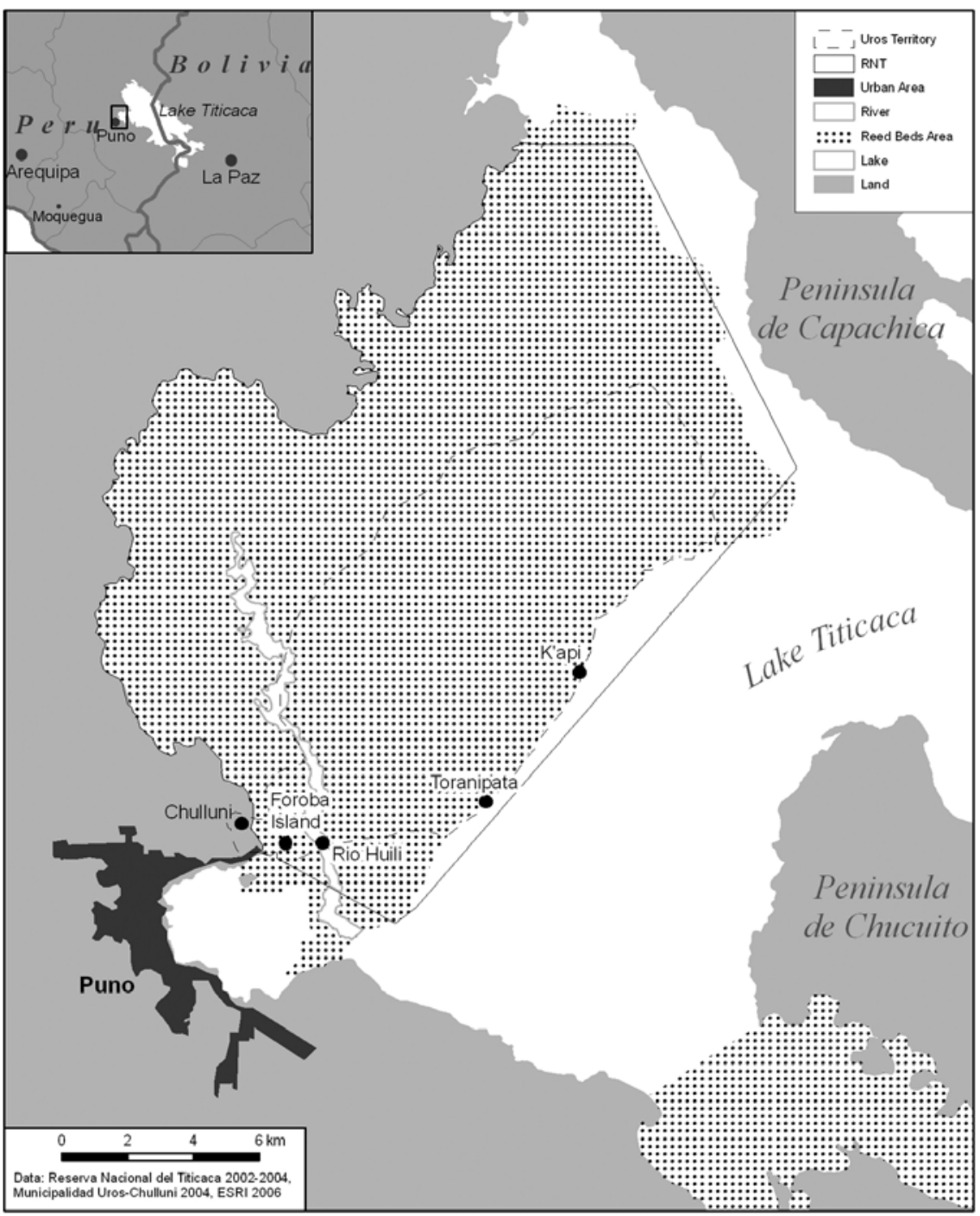

na localização, no tamanho ou na população de uma ilha estivesse sujeita à aprovação prévia das autoridades. Embora inicialmente bem-sucedida e apoiada pela maioria da população das ilhas, esta política terminou por ter o efeito inverso: resultou numa proliferação ainda mais acelerada de ilhas, que chegaram a cerca de 30 no final de abril daquele ano. 
No encontro do início de maio, diversos participantes culparam o prefeito dos Uros, Juan Coila, por sua desintegração, argumentando que ele deveria ter sido mais rigoroso. Visivelmente exasperado, Juan respondeu:

Sim, eu gostaria de ter feito isso. Eu fiz licenças para cada ilha. Mas o que posso fazer se vou até uma ilha para entregar a licença e descubro que ela foi separada? [...] Cada vez que venho aqui vocês têm mais ilhas, vocês mudam os nomes delas, mudam de presidente só para se divertir. Assim eu não consigo trabalhar!

Outros participantes, por sua vez, colocavam a culpa no caráter compulsório das medidas, que tinha causado conflitos internos nas ilhas. Esses desdobramentos sugerem que estava em jogo, na tentativa de unir as ilhas, uma tensão entre diferentes abordagens em relação à territorialidade. Especificamente, ela envolveu um choque entre as práticas costumeiras da população das ilhas, altamente flexíveis e voláteis, e as técnicas introduzidas por suas autoridades, voltadas para o controle e a fixação das práticas territoriais.

As autoridades dos Uros tinham se familiarizado com a abordagem de fixação da territorialidade em função de seu envolvimento conflituoso com a Reserva Nacional do Titicaca. Essa área protegida, gerida pelo Estado, foi criada em 1978 com o objetivo de regular o uso de recursos naturais na área dos juncais. Desde 2001, suas tentativas de adquirir o controle sobre o turismo das ilhas flutuantes e dominar as práticas territoriais flexíveis da população das ilhas levaram ao progressivo conflito com os Uros. Para manter um nível relativo de autonomia, os Uros e suas autoridades exigiram o reconhecimento formal daquilo que alegavam ser seu território aquático costumeiro, bem como sua conversão numa Reserva Comunal. No sistema de áreas protegidas do Estado peruano, este tipo de Reserva é confiado à administração direta das populações indígenas.

Como parte de sua campanha para o reconhecimento da Reserva Comunal, os Uros construíram uma definição precisa do seu território e de suas fronteiras, produziram mapas profissionais e elaboraram planos de zoneamento. Eles tinham se apropriado dessas técnicas de fixação de práticas territoriais do exemplo da própria Reserva Nacional. Esta estratégia foi bastante bem-sucedida e rendeu aos Uros amplo apoio político para a criação oficial da Reserva Comunal, incluindo o do então presidente Alejandro Toledo. A população das ilhas flutuantes sustentou essas estratégias e deu às suas autoridades uma relativa liberdade em suas negociações com o Estado. 
Figura 1 - Ilhas flutuantes

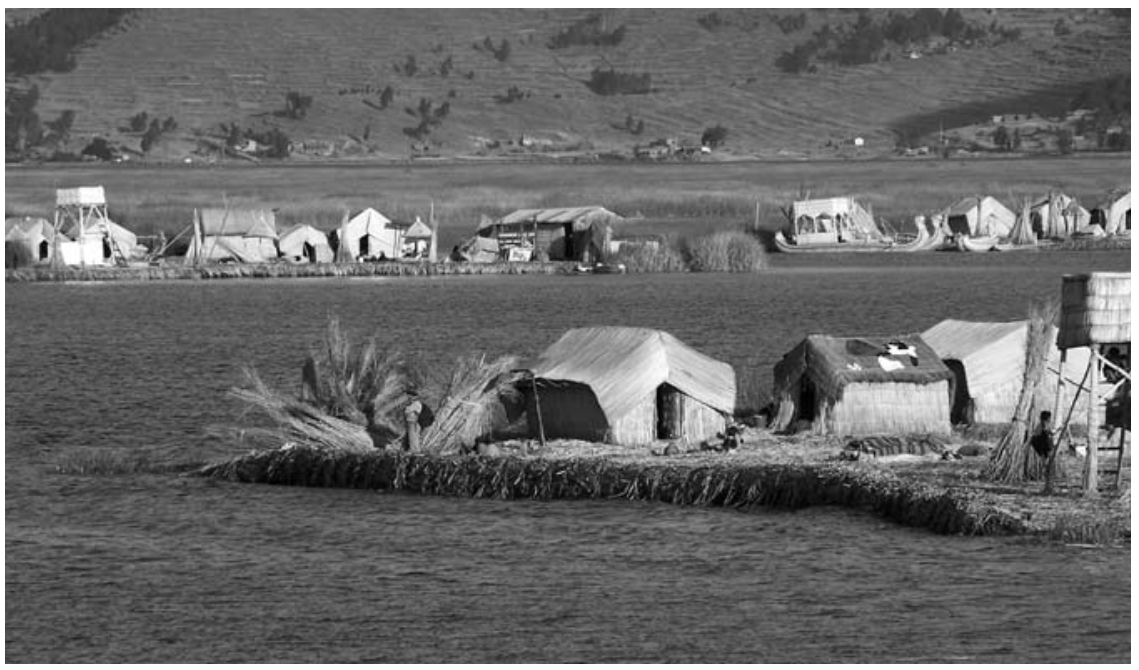

Contudo, o conflito com a Reserva Nacional não apenas tinha familiarizado os Uros e suas autoridades com a abordagem mais fixa do Estado sobre a territorialidade, mas também com a ideia de que uma maneira de lidar com uma situação como esta produziria efeitos políticos positivos. Como consequência, técnicas voltadas para a fixação das práticas territoriais tornaram-se cada vez mais atraentes como ferramentas para a solução de problemas sociais internos. A tentativa malograda de unir as ilhas flutuantes em 2005 foi a primeira vez em que essas técnicas foram aplicadas dentro da comunidade. O que ela revelou, em particular, foi que os habitantes das ilhas flutuantes estavam muito menos dispostos a aceitar tais mecanismos de controle territorial em suas vidas cotidianas do que em suas estratégias políticas externas. Dessa forma, essa tentativa redundou na reprodução, em nível da comunidade, das tensões entre as abordagens flexíveis e fixas da territorialidade que haviam emergido anteriormente na relação entre os Uros e o Estado.

O objetivo deste artigo é explorar no detalhe etnográfico essa tensão entre flexibilidade e fixação nas práticas territoriais de populações indígenas, bem como suas consequências sociais. Isto será realizado por meio da análise das interações dinâmicas entre as práticas territoriais que os Uros desenvolveram em nível comunitário e aquelas que medeiam suas relações com o mundo exterior, em especial com o Estado peruano. Este artigo, portanto, primeiro discutirá as práticas territoriais costumeiras nas ilhas dos Uros. Em seguida, voltarei minha atenção para as transformações nas 


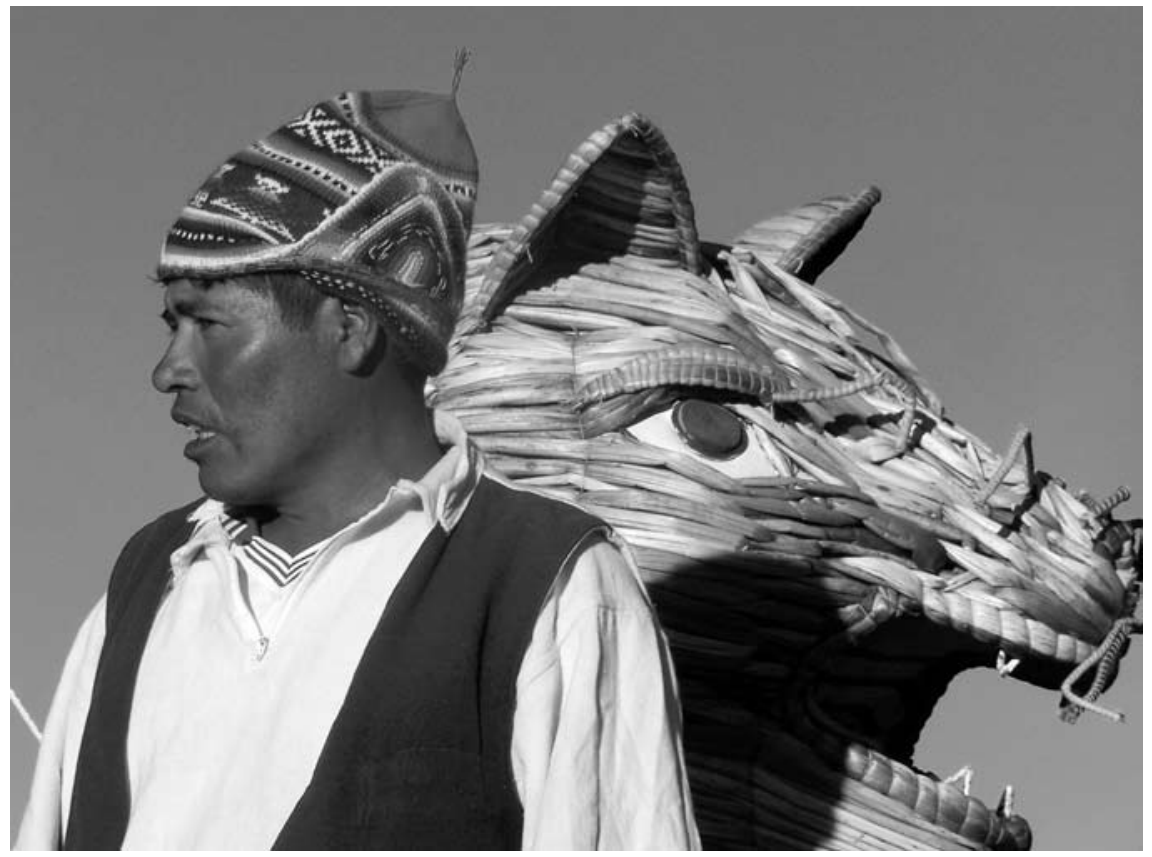

práticas territoriais nos juncais que resultam do encontro entre os Uros, a Reserva e as diversas outras comunidades indígenas. Por fim, o foco voltará ao aspecto comunitário, de modo a explorar as consequências de tais transformações nas práticas territoriais nas ilhas flutuantes. Primeiro, contudo, o artigo será iniciado com algumas considerações teóricas em relação às práticas territoriais indígenas e estatais.

\section{Processos de territorialização}

Desde os anos 1990, populações indígenas da América Latina têm reivindicado cada vez mais os territórios aos quais se referem como "costumeiros". Esses movimentos revelam uma homogeneidade notável em suas táticas, em seus quadros referenciais e nos termos com os quais expressam suas demandas. Em grande medida, isto é resultado de sua articulação com atores transnacionais, o uso de instrumentos jurídicos internacionais e a apropriação de discursos genéricos sobre indianidade e meio ambiente (Albert 2004; Brysk 2000; Ramos 1998; Sieder 2002; Van Cott 1994). 
No entanto, o contraste significativo entre as práticas territoriais altamente flexíveis nas ilhas flutuantes e os modos mais formais e fixos por intermédio das quais os Uros construíram suas reivindicações por um território costumeiro torna necessário qualificar a homogeneidade de tais demandas. O contraste sugere que uma heterogeneidade considerável nas práticas territoriais cotidianas entre as comunidades indígenas subjaz em relação à aparente homogeneidade das demandas externas. Além disso, dá a entender que as formas específicas - por meio das quais as reivindicações dos territórios costumeiros são modeladas — podem ser parte de um "formato" através do qual os grupos indígenas se projetam na arena política, uma linguagem em comum e regras compartilhadas do jogo aceitas por todas as facções envolvidas no encontro entre Estados e povos indígenas.

De modo a interpretar corretamente os processos territoriais que acontecem na Baía de Puno, é preciso notar que o território não é um dado natural, e sim uma "invenção historicamente datada" (Alliès 1980:25). Diversos estudos relativamente recentes abordaram a territorialidade como processo, como construção social e histórica (em especial Alliès 1980; Augé 1992; Brunet 1986; Certeau 1980; Deleuze \& Guattari 1992; Green 2005; Gupta \& Ferguson 1992, 1997; Hirsch 1995; Mallki 1997; Oliveira 1998; Raffestin 1986; Rappaport 1985; Rodman 1992). A partir desta perspectiva, a ideia de uma territorialidade reificada deveria ser substituída pelo foco nos "processos de territorialização" (Oliveira 1998:56). A tarefa de um antropólogo, então, é "prestar especial atenção às formas pelas quais espaços e lugares são criados, imaginados, contestados e impostos" (Gupta \& Ferguson 1992:18). Metodologicamente, estes lampejos implicam uma mudança de foco das condições físicas dos territórios ou das regras de propriedade para os contextos sociais e as relações de poder nos quais a territorialidade é produzida. Abordar o território como o efeito temporário de um processo contínuo permite sua conceituação como algo que é flexível, sujeito à mudança e que pode se transformar em vez de ser fixo.

Como ilustra o caso dos Uros, as práticas indígenas territoriais em específico revelam níveis expressivos de heterogeneidade e flexibilidade. Nos Andes existe uma extensa variedade de princípios organizadores de pertencimento e controle territorial (Lehmann 1982; Rappaport 1985). A noção de comunidade não é estritamente relacionada a um território demarcado e contínuo. Nos tempos pré-coloniais, a organização territorial nos Andes era caracterizada pelo sistema arquipélago: grupos e comunidades étnicos controlavam territórios descontínuos, espalhados por diferentes zonas ecológicas, de forma a otimizar seu acesso a recursos essenciais 
(Murra 1975). Resíduos deste sistema ainda são responsáveis por descontinuidades nas práticas territoriais contemporâneas. Isto se reflete na cosmologia andina, em que fronteiras são instáveis e movediças, já que o movimento e a flexibilidade são priorizados em detrimento da estase (Bouysse-Cassagne \& Harris 1987).

Os Estados têm desempenhado um papel importante nos processos de territorialização pela transformação — com a mediação da lei — de espaços heterogêneos e limites flexíveis em territórios homogêneos com fronteiras fixas (Alliès 1980; Bourdieu 1980). A apropriação do espaço pelo aparato administrativo tem sido crucial para a expansão do controle do Estado sobre populações e recursos (Alonso 1994; Ferguson \& Gupta 2005; Lacoste 1986; Lima 1995; Scott 1998). Desde a segunda metade do século XIX, o estabelecimento de áreas protegidas desempenhou um papel importante na territorialização do poder estatal (MacKenzie 1990; Nash 1970; Spence 1999; Vandergeest \& Peluso 1995).

O encontro entre as concepções territoriais do Estado e os entendimentos indígenas sobre seu ambiente muitas vezes resultou em mudanças consideráveis para estes últimos. De acordo com Geertz, o territorialismo não é uma simples sobrevivência do passado distante, mas o resultado da interação entre valores tradicionais e os acontecimentos pouco tradicionais do século XX (Geertz 1959). A luta política dos grupos indígenas para manter ou recuperar o controle da área que habitam não apenas produz mudanças naquele território, mas também em suas concepções a respeito do que seja um território e em sua relação com populações vizinhas (Albert 2004; Creamer 1988; García Hierro \& Surrallés 2004; Peluso 2005; Viesner 2002). O estabelecimento de um sentido de territorialidade em meio a grupos indígenas está, muitas vezes, diretamente relacionado à invasão externa das áreas que habitam (Gallois 1998; Oliveira 1998).

Os Estados desempenham, portanto, um papel importante ao provocarem a territorialização do espaço de grupos locais como estratégia de defesa contra a sua invasão. Assim, ao invés de supor a preexistência de territórios indígenas costumeiros, é preciso explorar como os entendimentos de possuir um território fixo são moldados e experimentados (Ferguson \& Gupta 2005:7); em outras palavras, como a ideia de um território demarcado e fixo torna-se socialmente aceitável. Estas inspirações teóricas tornam necessário tratar das duas questões centrais e interrelacionadas deste artigo. Primeiro, as tensões entre a flexibilidade que caracteriza as práticas territoriais nos Andes e as investidas do Estado na fixação. Segundo, a interação dinâmica entre práticas territoriais no nível da comunidade e as práticas que medeiam relações com o mundo exterior. 


\section{Práticas territoriais, mobilidade física e flexibilidade social dos Uros}

Os Uros geralmente se definem como "povo do lago". Suas vidas estão intimamente ligadas ao lago e a seus recursos. Aproximadamente $60 \%$ da população vivem nas ilhas flutuantes em meio aos extensos juncais da Baía de Puno, enquanto os demais se estabeleceram em terra firme, no povoado de Chulluni, numa pequena porção de terra concedida a eles em 1975 durante a Reforma Agrária. Os Uros usam os juncos para a construção de suas ilhas, casas e balsas, bem como para a produção de artesanatos vendidos aos turistas. Originalmente caçadores de aves e pescadores, a partir dos anos 1970 um número crescente de Uros passou a se envolver com uma próspera indústria do turismo, que traz centenas de milhares de visitantes às ilhas flutuantes por ano.

Eles afirmam que são descendentes dos antigos Urus, geralmente considerados o primeiro grupo étnico a habitar os Andes e que constituíam um quarto da população da bacia hidrográfica do Titicaca na época da conquista pelos espanhóis (Kent 2011; Wachtel 1990). ${ }^{2}$ Atualmente, os Uros têm uma estrutura de autoridade política dupla. Em 2001, foi criado o município de Uros-Chulluni, baseado em Chulluni. Suas autoridades principais são o prefeito e cinco vereadores. Os assuntos internos da área das ilhas flutuantes são administrados pelo conselho diretivo das ilhas, que consiste em um presidente, um secretário e um tesoureiro. Eles presidem duas reuniões mensais, em que cada ilha é representada por seu próprio presidente.

O número e o tamanho das ilhas têm variado de forma significativa ao longo do tempo. O rio Huili, um rio natural que atravessa os juncais a uma distância de sete quilômetros da capital Puno, é a área que atualmente abriga a maior concentração de ilhas flutuantes. Desde que iniciei o trabalho de campo, em 2003, o número de ilhas nessa área variou entre sete e 60, e sua população entre duas e 24 famílias por ilha.

A condição flutuante das ilhas resultou numa forma muito particular de sociabilidade entre os Uros. A mobilidade física é uma característica central de suas vidas cotidianas, o que pode acarretar problemas incomuns, como ilustra a anedota a seguir. Numa noite de tempestade, meu compadre Julio voltou remando de uma visita a Puno. Quando chegou à localidade de sua ilha, no entanto, constatou que ela desaparecera. Como ele conta, "Fui até os meus vizinhos e perguntei se eles tinham visto a minha ilha, mas não. Então fui de ilha em ilha perguntando 'onde está a minha ilha?', 'para onde foi a minha ilha?', mas ninguém sabia". Só quando a mulher de Julio queimou fogos de artifício, na hora em que ela esperava que ele voltasse para casa, ele conseguiu encontrar novamente sua ilha. O temporal fizera com 
Figura 3 - Transportando os juncos

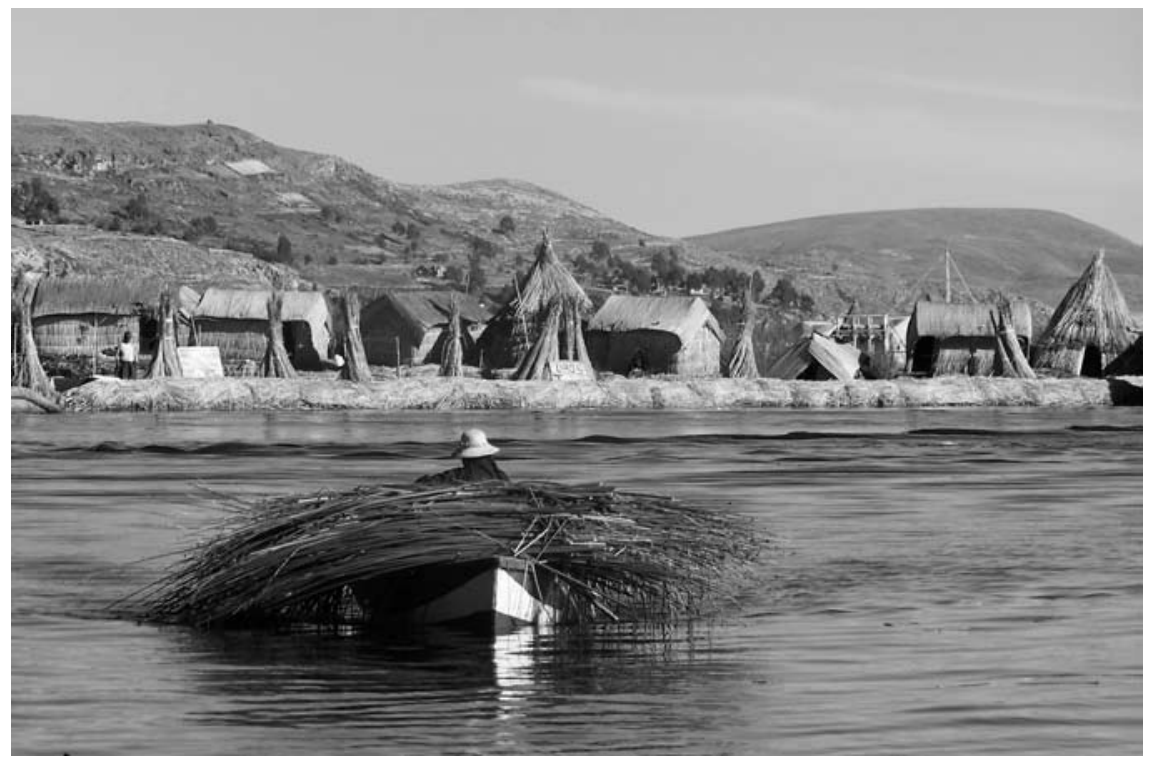

que a ilha ficasse à deriva, deslocando-a mais de um quilômetro. As ilhas flutuantes são atracadas no fundo do lago com troncos de árvores e cordas grossas. Não obstante, são vítimas fáceis das duras condições climáticas no lago, havendo com frequência ilhas vagando à deriva. Em 1987, temporais extremamente fortes destruíram três grandes ilhas situadas nas margens entre os juncais e o lago aberto, suas partes estilhaçadas errando por toda a Baía de Puno e além. Depois de ter desaparecido por dois dias, uma mulher idosa foi encontrada flutuando em lago aberto, perto da costa boliviana.

Contudo, como a introdução já ilustrava, não são apenas os elementos da natureza que movem as ilhas de uma parte a outra. Os Uros também o fazem, usando a prerrogativa da mobilidade como solução para uma extensa variedade de desafios climáticos, sociais e econômicos que enfrentam. Os níveis do Lago Titicaca estão sujeitos a importantes flutuações, não apenas entre as estações de estiagem e de chuvas, mas também entre ciclos maiores de seca e enchente. Na Baía de Puno, algumas vezes os juncais secam e se transformam em terra firme, enquanto outras vezes ficam inteiramente submersos pela água. Dessa forma, tanto o lago quanto os juncais podem desaparecer inteiramente por anos a fio.

Essas variações periódicas nos níveis do lago impedem a fixação definitiva dos Uros, já que níveis diferentes tornam diferentes áreas dos juncais 
mais adequadas à moradia. Como resultado, os Uros têm historicamente ocupado áreas distintas nos juncais. Por exemplo, embora no início vivessem em pequenas ilhas espalhadas pelos juncais, no início dos anos 1940 a seca mais severa do século XX obrigou-os a se dirigirem às margens do lago aberto. A emergência do turismo tem contribuído fortemente para os processos migratórios: desde o princípio dos anos 1970 tem acontecido um constante movimento de ilhas flutuantes, dependendo das mudanças nas rotas principais do turismo, com os Uros cada vez mais gravitando por áreas mais acessíveis a partir de Puno, o centro turístico regional. Quando em 1987 a enchente mais séria do século XX combinou-se com um clima extremo e destruiu a maior parte das ilhas às margens dos juncais, a maioria dos Uros deslocou-se para um local mais protegido do rio Huili.

Assim, o senso de pertencimento dos Uros não se vincula a pontos fixos determinados no espaço, mas sim a um ambiente específico: o lago e seus juncais. Essa relação com um habitat distintivo ao invés de um espaço específico tem raízes históricas. Em épocas pré-hispânicas, os Uros não ocupavam um espaço delimitado e contínuo, mas sim diversos arquipélagos dispersos, consistentes com o mesmo ambiente: água e juncais (Wachtel 1990).

A flexibilidade social é outro fator característico da vida nas ilhas flutuantes. Como foi ilustrado na introdução, pela prática de separar ilhas em conflito, a estrutura física flexível das ilhas abre toda uma série de possibilidades de modelagem da vida social de maneiras inimagináveis para populações que vivem em terra firme. A divisão e a união de ilhas são também usadas como um recurso político. Quando, em 2005, os Uros mantiveram um guarda florestal da Reserva como refém por mais de um dia na ilha de Tribuna, o promotor público abriu procedimentos criminais contra as autoridades principais dos Uros. Como procedimento padrão de uma investigação criminal, uma delegação, que incluía o juiz designado e o promotor público, decidiu visitar a ilha de Tribuna, então definida como cena de crime. Para evitar se envolver, a população da ilha inventou a seguinte solução, como um deles explicou:

Decidimos separar a ilha. Demos às duas partes novos nomes e puxamos a escola para o lado oposto do rio Huili. Então, no dia em que a delegação chegou para inspecionar o lugar, eles perguntavam "onde está a ilha de Tribuna?". E todos respondiam "qual ilha?", "nunca ouvi falar", ou "não existe nenhuma Tribuna". Assim foi como nos salvamos.

Desta forma, o habitat móvel e as práticas territoriais flexíveis dos Uros permitiram que se desmanchasse no ar o que tinha sido definido como uma cena de crime. 
Para uma família é ainda mais fácil se separar de uma ilha; tudo o que precisa fazer é cortar as cordas de sua plataforma de junco particular. Assim, à mobilidade das ilhas flutuantes corresponde a circulação de indivíduos ou famílias Uros entre ilhas. Ao longo do curso de suas vidas, a maior parte dos Uros terá morado em pelo menos meia dúzia de ilhas diferentes. Julio, por exemplo, aos 37 anos tinha circulado entre sete ilhas. Ao recontar sua trajetória de vida, as razões dadas para mudar de ilha incluíam casamento, conflitos com companheiros ilhéus, melhores oportunidades de trabalho no turismo e um emprego na escola da ilha de Tribuna. Ele concluiu com a seguinte reflexão:

No lago é bem fácil; se você não está contente, você pega a sua plataforma e vai para outro lugar. Você não pode fazer isso na terra, se você tem uma briga com os seus vizinhos, você não pode se mudar, ou você tem que vender sua casa e tudo. Aqui no lago você pode se mudar quantas vezes quiser.

Assim, para os habitantes das ilhas flutuantes, mudar de um lugar para outro é uma resposta facilmente disponível para lidar com uma variedade de situações, incluindo o conflito social, novas oportunidades econômicas ou mudanças nas relações de parentesco. Essa mobilidade física tem paralelo na flexibilidade social, já que mudar de ilha normalmente envolve travar um novo conjunto de relações. Em suma, tanto em nível individual quanto coletivo, as vidas sociais e as práticas territoriais dos Uros desenvolvem-se em um fluxo permanente entre união e separação. Se as alianças são sempre relativamente frágeis, as rupturas nunca são permanentes. Uma separação é simples de desfazer, e é bastante comum que famílias que um dia estiveram em lados opostos depois da separação de uma ilha se unam novamente em um ou outro momento.

Para muitas populações nômades ao redor do mundo, envolver-se nos processos variados associados à modernidade resultou em uma obliteração gradual de sua característica móvel e das especificidades culturais que dela resultam (Casimir \& Rao 1992). Entre os Uros, contudo, parece se dar o oposto. Como foi discutido na introdução, o desenvolvimento do turismo e a competição interna pelos benefícios por ele gerados resultaram numa proliferação de ilhas, tendo aumentado a volatilidade das práticas territoriais dos Uros.

A seguir, voltarei minha atenção para o contexto social e político mais amplo no qual os Uros operam, apenas para retornar às suas práticas territoriais internas na última seção deste artigo. A seção seguinte introduzirá as comunidades ribeirinhas e a Reserva Nacional do Titicaca, bem como suas práticas territoriais e suas relações com os Uros. 


\section{Os Uros, as comunidades ribeirinhas e a Reserva}

Além dos Uros e da população urbana de Puno, a Baía de Puno também acolhe uma densa população ribeirinha de mais de 100.000 pessoas, constituída por Quechuas, em sua costa oeste e norte, e Aymaras, do lado sudeste. A criação de rebanhos de gado em pequena escala é a atividade econômica predominante dessas comunidades. Isto faz dos juncos um recurso importante também para elas, servindo de forragem durante os invernos secos quando o pasto se esgota na terra firme. De maneira a garantir seu acesso aos juncos, as comunidades ribeirinhas estabeleceram direitos territoriais privilegiados em relação às seções do lago adjacentes à sua costa. Ben Orlove e Dominique Levieil documentaram amplamente a onipresença de territórios aquáticos costumeiros no Lago Titicaca (Levieil \& Orlove 1990; Orlove 1991, 2002). Em função de variações na profundidade do lago, os juncais são distribuídos de maneira desigual. Por isso, comunidades com um excedente de juncos frequentemente permitem que estranhos cortem juncos em seu território em troca de diversas coisas, incluindo o acesso às terras de pasto, a execução de tarefas de manutenção nos diversos canais que cortam por entre os juncais ou o pagamento direto, em forma de comida ou dinheiro.

O denominador comum "comunidades ribeirinhas" representa inúmeras e diferentes formas de organização social, bem como relações bastante heterogêneas entre pessoas e lugares. Comunidades camponesas, parcialidades, anexos, Centros Poblados e grupos de herdeiros de famílias donas de terras reivindicam partes dos juncais da Baía de Puno. Além disso, arranjos costumeiros mostram uma mistura complexa entre propriedade coletiva e privada. Enquanto os juncais de algumas comunidades são divididos em lotes de propriedade privada de famílias, em outros casos todo o território aquático de uma comunidade está aberto a cada um de seus membros.

Esses territórios não são exclusivos, e seus limites são permeáveis mesmo em áreas em que os juncais são divididos em lotes familiares. À medida que a entrada ocasional é tolerada, é mais frequente as pessoas de outras comunidades terem permissão de cortar juncos em troca de alguma comida ou acesso ao pasto. Portanto — tal como no caso dos Uros - as práticas territoriais das comunidades ribeirinhas são caracterizadas por altos níveis de flexibilidade, limites relativamente permeáveis e uma mobilidade considerável. As ambiguidades resultam, em parte, do uso de fatores naturais como marcas desses limites, muitos dos quais não são pontos fixos no espaço. Este é o caso específico das faixas de juncos, que podem se tornar móveis ao se desprenderem do fundo do lago e cuja constelação também muda com as variações nos níveis do lago. 
Essa mesma flexibilidade caracterizava, até recentemente, a relação entre as comunidades ribeirinhas e os Uros. Os Quechuas cortadores de junco, bem como caçadores e pescadores Uros circulavam continuamente, entrando e saindo dos territórios de cada um sem grande impedimento. Como acontece no ambiente climático de alto risco dos Andes, essa flexibilidade é um importante elemento de estratégias de atenuação de riscos. Por exemplo, quando nas épocas de seca os juncos escasseiam mais perto da costa, os pastores de gado da beira do lago passam a precisar de acesso às partes mais profundas e distantes dos juncais. Da mesma forma, quando durante períodos de cheia no lago os pássaros afluem para as partes mais rasas perto da costa, os caçadores Uros passam a depender dos territórios ribeirinhos.

No caso das populações Aymaras da costa sul, arranjos foram estabelecidos em termos mais formais, de acordo com os quais os Uros alugavam partes dos seus juncais (Orlove 1991). ${ }^{3}$ A permeabilidade de limites também se aplicava a ilhas flutuantes inteiras, que em diversas ocasiões eram toleradas dentro de territórios das comunidades ribeirinhas. Estas flexibilidade e abertura de fronteiras desaparecem por completo, no entanto, em épocas de seca rigorosa, quando os juncais se tornam terra firme. Durante esses períodos - o mais recente deles ocorrido entre 1996 e 2000 - conflitos territoriais tornam-se generalizados pelos juncais, pois pessoas entram na área com seu gado, plantam e fincam marcas claras de fronteiras.

Em 1978, os juncais da Baía de Puno foram declarados área protegida através da criação da Reserva Nacional do Titicaca, atualmente administrada pelo Instituto Nacional de Recursos Naturais (INRENA), de caráter estatal. Foi apenas em 1996, no entanto, que uma subvenção de dez anos do governo alemão proveu os fundos necessários para a efetiva administração da Reserva. ${ }^{4}$ Desde então, sua administração tem revelado uma orientação territorializante pronunciada, por exemplo, por meio de esforços para colocar boias e placas de informação em seus limites, inscrever sua propriedade legal dessa área em registros públicos e patrulhar os juncais. A produção de um corpo de mapas e o estabelecimento de subdivisões territoriais também projetaram uma qualidade cada vez mais fixa ao território da Reserva. Para poder demarcar sua fronteira com a terra pertencente às comunidades ribeirinhas, a Reserva lidou com ciclos periódicos de aumento e queda dos níveis do lago por meio do estabelecimento de uma linha fictícia dividindo o lago e a terra.

O caráter móvel das práticas territoriais dos Uros também foi alvo de intervenções por parte da Reserva. Por exemplo, em 2001 a Reserva tentou "fixar" o contínuo movimento das ilhas flutuantes dos Uros ao impor um sistema de licenças para as ilhas, tornando qualquer mudança em seu número, 
em seu tamanho ou em sua localização sujeita à aprovação da Reserva. Este plano foi abandonado depois da forte oposição dos Uros, que o viram como uma ameaça à sua autonomia e à sua prerrogativa de mobilidade. De 2005 em diante, tornou-se um objetivo explícito da administração da Reserva estabelecer os Uros em terra firme, mantendo apenas um número limitado de ilhas modelares para propósitos turísticos. Assim, a pronunciada investida fixadora da Reserva contrasta significativamente com as formas pelas quais os Uros e as populações ribeirinhas se relacionam com os juncais.

Desde 1996, os esforços da Reserva para regular o uso de recursos nos juncais constituíram outro motivo para aumentar as tensões com os Uros. No entanto, a partir de 2001, foram as tentativas da administração de obter controle sobre o lucrativo empreendimento turístico centrado nas ilhas flutuantes o que levou ao conflito aberto (Kent 2006). Como resposta, os Uros tentaram manter o domínio do turismo em seu território ao demandarem a sua conversão em Reserva Comunal, uma categoria no sistema de áreas protegidas do Peru concebida para a administração direta por populações indígenas. Em junho de 2002, os Uros ocuparam o centro de controle principal da Reserva na ilha Foroba e declararam unilateralmente a criação da Reserva Comunal. Estabelecendo sua própria rede de guardas florestais, desde então eles têm impedido a Reserva de patrulhar a área. Ao apelarem para a sua identidade indígena distintiva e os seus direitos costumeiros, os Uros mobilizaram com sucesso a opinião pública, bem como um número cada vez maior de atores regionais e nacionais do Estado, em prol da criação da Reserva Comunal, incluindo Alejandro Toledo, presidente do Peru.

Como resposta, a Reserva construiu alianças com comunidades ribeirinhas que viam seu acesso aos juncais ameaçado pelos planos da Reserva Comunal dos Uros. Juntos reconstruíram os territórios aquáticos costumeiros dessas comunidades, criando reivindicações concorrentes nas quais o território dos Uros era expressivamente reduzido. A Reserva elaborou um Mapa de Zonas de Uso Ancestral para apoiar essas reivindicações. Comitês de Conservação locais foram estabelecidos em comunidades ribeirinhas, e a Reserva treinou guardas florestais comunitários para patrulhar seus territórios aquáticos, assim impedindo os Uros de imporem suas reivindicações em definitivo. Confrontos entre os Uros, a Reserva e as comunidades ribeirinhas cresceram gradativamente, culminando com um grande conflito de rua que deixou dezenas de feridos na capital regional de Puno, em 2005. Por fim, em 2006, o Estado peruano reconheceu oficialmente os direitos das comunidades ribeirinhas aos seus territórios aquáticos. ${ }^{5}$

Assim, ao invés de uma oposição estrutural, este conflito revela entrelaçamentos complexos de uma variedade de atores do Estado e grupos indí- 
genas, tanto em nível político como conceitual. Esses emaranhados resultam do intenso trançar e misturar de alianças, estratégias, argumentos e sistemas normativos (Kent 2009). Este contexto nebuloso é de importância crucial para entender a transformação das práticas territoriais que foi deflagrada pelo confronto a propósito dos juncais, a ser discutido em seguida.

\section{Conflito político e a transformação de práticas territoriais}

Essa breve visão geral sobre a história do conflito revela que ele resultou na introdução de novos estatutos territoriais nos juncais da Baía de Puno, como as Zonas de Uso Ancestral e a Reserva Comunal. Também provocou profundas transformações nas abordagens e nas práticas territoriais implicadas nas relações entre os Uros, as comunidades ribeirinhas e a Reserva. Tais transformações são mais bem ilustradas ao se contrastarem as situações antes e depois da emergência do conflito.

No ano 2000, uma seca rigorosa converteu os juncais em terra firme. Isto provocou disputas territoriais intensas envolvendo diversas comunidades ribeirinhas e os Uros. Para mediar esses conflitos, a Reserva organizou uma reunião com as autoridades dos Uros e 16 comunidades ribeirinhas. As atas deste encontro registram que: "Todos os delegados se comprometem a respeitar os limites ancestrais, reconhecendo a área de recreação ${ }^{6}$ de aproximadamente 10.000 hectares como limite da comunidade Uros-Chulluni".

Outros documentos também revelam que, naquela época, os Uros reivindicavam uma área vagamente definida de "aproximadamente 10 mil hectares" sem nenhuma fronteira explícita. Além disso, nas atas, as comunidades ribeirinhas definiam suas próprias áreas como "não tendo limites". Assim, territórios costumeiros existiam então, mas não eram claramente definidos e não tinham limites precisos. As atas dessas reuniões revelam também que a Reserva e as comunidades ribeirinhas reconheciam explicitamente esta área de cerca de 10.000 hectares como pertencente aos Uros. No ano 2000, em diversas ocasiões, funcionários da Reserva chegaram a atuar em defesa dos Uros ao expulsarem populações ribeirinhas ou seu gado desta área.

Em 2004, no entanto, líderes Uros já reivindicavam um território aquático definido com precisão: 11.383,75 hectares. Eles apoiaram suas reivindicações em mapas profissionais, uma definição de fronteiras em coordenadas dadas por GPS, documentos emitidos pelas instituições regionais do Estado reconhecendo a legitimidade de suas reivindicações e documentos antigos que atestavam a propriedade de partes da área. Os Uros argumentaram 
que a criação da Reserva em 1978 significou a usurpação de seu território costumeiro, há muito estabelecido. Eles enfatizaram a antiguidade dos seus direitos por meio da vinculação retórica de sua presença nos juncais aos tempos das populações pré-coloniais Uru.

A administração da Reserva e as autoridades do Comitê de Conservação, por sua vez, argumentavam que o conflito era causado pela invasão dos territórios costumeiros das comunidades ribeirinhas, nos juncais, pelos Uros. Para apoiar esse raciocínio, eles elaboraram um mapa que define precisamente essas "Zonas de Uso Ancestral" (ver mapa 2). Nesse mapa, os Uros recebem uma área residual não reivindicada por nenhuma comunidade ribeirinha, limitando seu território a 3.003,90 hectares, ou 26\% do que demandavam. As populações ribeirinhas também apoiaram suas reivindicações em referências frequentes a documentos antigos - títulos de propriedade, transações de vendas ou decisões judiciais - e no estabelecimento ou na defesa de seu território por seus ancestrais. De acordo com os Uros, o mapa de Zonas de Uso Ancestral, no entanto, deliberadamente infla os territórios aquáticos das comunidades ribeirinhas. A sobreposição das reivindicações territoriais dos Uros e das comunidades ribeirinhas é mostrada no mapa 2 .

Embora representações contrárias do conflito coexistissem, elas tinham algo em comum: supunham a preexistência de territórios costumeiros claramente definidos e exclusivos, que precisavam ser defendidos de apropriações externas ilegítimas. Isto foi agravado pelos quadros de referência das reivindicações dos Uros e das comunidades ribeirinhas, que mostram uma mistura de elementos antigos e modernos. Ambos os grupos expressavam suas reivindicações em uma linguagem de ancestralidade, fazendo alusões frequentes a velhos documentos e a ancestrais que defenderam o território antes deles, com isto traçando simbolicamente uma linha no tempo de continuidade territorial e sua defesa incansável. Ao mesmo tempo, também fizeram uso de técnicas modernas para a definição precisa de territórios, como mapas, planos de zoneamento, coordenadas de GPS e a expressão de tamanho em hectares, com até dois dígitos depois da vírgula decimal, ou seja, chegando ao metro quadrado. Isto sugere que, em um intervalo relativamente curto de tempo - não mais do que quatro anos - uma transição bastante profunda tomou lugar: de uma forma mais aberta e permeável de territorialidade para uma modalidade mais fechada e fixa. As próximas duas seções explorarão como esta transformação aconteceu na prática, analisando separadamente os processos interrelacionados por meio dos quais os territórios na Baía de Puno se tornaram (a) definidos com precisão e (b) interditados para estranhos. 
Mapa 2 - Territórios reivindicados pelos Uros e pelas comunidades ribeirinhas

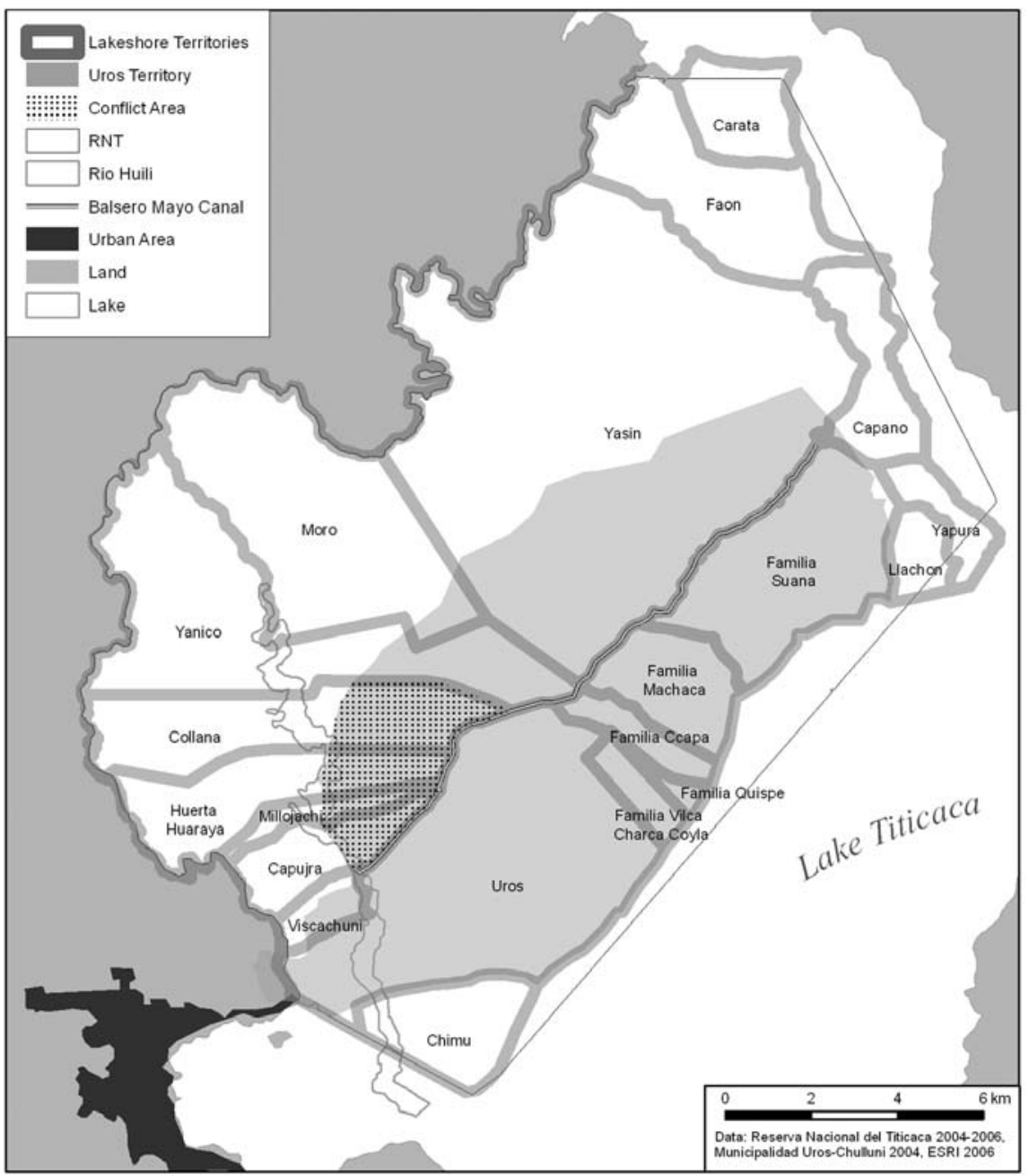

\section{A definição de territórios}

Para esta discussão, centrar-me-ei na área mais disputada nos juncais, destacada com pontilhado no mapa 2. De acordo com os Comitês de Conservação de Capujra, Millojachi, Huerta Huaraya e Collana, seus limites territoriais com os Uros eram estabelecidos pelo canal de Balsero Mayo. Na visão dos Uros, no entanto, era o rio Huili que formava seu limite comum. Ambos ale- 
gavam ter possuído a área entre o rio Huili e o Balsero Mayo desde "tempos ancestrais". Contudo, como discuti anteriormente (Kent 2008), um exame dessa ocupação histórica complica esse quadro. Embora os Uros e as comunidades ribeirinhas tenham estado presentes, no transcorrer do século XX, na área sob contenda, eles o fizeram em períodos diferentes, com intensidade relativamente baixa e sem engajar-se em contato substancial.

Os Uros foram os primeiros a formalizar suas reivindicações para a área contestada, em 1975, durante o processo que levou ao seu reconhecimento como uma comunidade camponesa. Embora as restrições impostas pela Lei da Água tenham limitado o território formal da comunidade a 78 hectares em terra firme, a instituição estatal responsável pela reforma agrária também demarcou precisamente o território aquático nessa ocasião. Durante uma expedição de dois dias, funcionários do Estado e autoridades dos Uros viajaram pelos juncais e registraram as fronteiras deste grupo. Antes disso, eles tinham solicitado às comunidades ribeirinhas, aos donos de terras e a outros grupos vizinhos que colocassem bandeiras nos limites de seus territórios. Depois de admitir que o território original dos Uros era delimitado pelo Balsero Mayo, Romualdo - uma das autoridades dos Uros que participavam da demarcação - falou sobre esta expedição: "Apenas as populações de Chimu e Yanico estavam lá com suas bandeiras. Onde não havia bandeira fincada, reivindicamos como nosso, assim foi como aumentamos nosso território".

Como resultado, o território aquático dos Uros foi definido em 11.383 hectares. Assim, eles formalizaram suas reivindicações para toda a área entre o rio Huili e o Balsero Mayo por omissão, já que, com poucas exceções, as comunidades ribeirinhas permaneceram ausentes. Subsequentemente, essa definição caiu no esquecimento, como ficou evidenciado pela demanda dos Uros, nos estágios iniciais de sua contenda com a Reserva, por um território de "cerca de 10.000 hectares". A definição de 1975 só foi recuperada por volta de 2001, quando uma demarcação territorial precisa tornou-se necessária como parte de suas requisições para as qualificações como município e Reserva Comunal. Este fato revela a relação próxima entre definições territoriais precisas e a necessidade de se conformar às categorias territoriais do Estado.

As comunidades ribeirinhas, por sua vez, formalizaram suas reivindicações para a área contestada a partir de 2002. Nesse meio tempo, a relação entre as populações Quechua, da costa noroeste, e os Uros mudara significativamente, em função da migração em massa destes últimos para o rio Huili e Chulluni a partir de 1987. A intensificação de contatos diretos que resultaram desta nova proximidade teve consequências contraditórias. 
Por um lado, levou ao estabelecimento de relações de compadrio entre cortadores de juncos da beira do lago e caçadores e pescadores Uros. Por outro lado, no entanto, também causou uma série de choques entre os dois grupos em razão da área entre o rio Huili e o Balsero Mayo, que se tornara importante nos anos 1990 por causa da seca rigorosa. Com a piora da seca, as populações ribeirinhas começaram a fazer seu gado pastar além do rio Huili, movendo-se cada vez mais perto da nova localização dos Uros. Apesar dos protestos enérgicos dos Uros, que dependiam dos juncos que iam ficando mais escassos nessa área para manter suas ilhas, o gado permaneceu ali. Como último recurso, os Uros organizaram, em duas ocasiões, uma batida para expulsar a população ribeirinha e seu gado daquela área.

Assim, quando os Uros intensificaram seus esforços por reconhecimento territorial, não foi apenas a Reserva que se sentiu ameaçada, mas também as comunidades ribeirinhas. Em meados de 2001, quando o governo municipal de Puno elevou o estatuto dos Uros-Chulluni de comunidade camponesa a município e reconheceu os 11.383 hectares aquáticos como parte de sua jurisdição, outro confronto direto aconteceu. Com documentos em mãos, os Uros formaram um grande grupo para inspecionar seu recém-reconhecido território e estabelecer marcas delimitadoras visíveis em suas fronteiras. Depois de terem encontrado pouca resistência nos juncais entre Capujra e Millojachi no primeiro dia de inspeção, na manhã seguinte as populações de Huerta Huaraya e Collana esperavam por eles em grande número. Uma batalha se sucedeu e os Uros não conseguiram demarcar suas fronteiras nessa área. O que se seguiu foi um efeito cascata de reivindicações territoriais e definições de fronteiras. Como explicou Ubaldo, secretário da direção do Comitê de Conservação e habitante de Huerta Huaraya:

Foi depois que os Uros vieram para demarcar seu território que tudo começou, "não toque nisto; isto é meu, meu, meu". Então, todo mundo começou a demarcar território. [...] Porque antes era livre. Claro que sabíamos que esta parte pertencia a Huerta, mas não nos importávamos se alguém viesse e cortasse juncos. Tínhamos mais que o suficiente, outros tinham pouco, então, podiam chegar e pegar. E os Uros vinham caçar e pescar. Como só usávamos os juncos, não era um problema.

Ainda assim, as comunidades entre Capujra e Collana apenas formalizaram suas reivindicações para a área entre o Balsero Mayo e o rio Huili durante a elaboração do mapa de Zonas de Uso Ancestral, ou seja, depois que os Uros e a Reserva tinham colidido em relação ao posto de controle na ilha Foroba, em junho de 2002. Assim, não foi apenas a sua disputa com os 
Uros durante a seca que detonou essa definição territorial, mas seu envolvimento com uma instituição estatal em conflito com os Uros. O incentivo para definir os territórios aquáticos das comunidades ribeirinhas veio da Reserva, como explicado por Miguel, chefe interino da mesma em três períodos entre 2000 e 2002:

Começamos com as Zonas de Uso Ancestral depois que os Uros tomaram a ilha de Foroba. Pensamos nisso como uma estratégia contra as suas reivindicações, mas não dissemos isso de maneira explícita às comunidades ribeirinhas. Eles se interessaram pela ideia porque também sentiam a pressão dos Uros.

Como essa foi uma estratégia deliberada de defesa contra as reclamações dos Uros, durante a demarcação dos territórios aquáticos, a Reserva e as comunidades ribeirinhas tinham o interesse comum em estender as fronteiras da comunidade para tão longe quanto possível lago adentro. No decorrer da elaboração do mapa, houve uma diferença nítida entre as formas com que se estabeleceram as fronteiras laterais entre comunidades ribeirinhas e suas fronteiras com os Uros, para dentro do lago. De acordo com Miguel,

Quando fizemos as inspeções visuais para demarcar os territórios dos Comitês, convidamos as autoridades da comunidade e de seus dois vizinhos do lado. Eles deveriam estabelecer sua fronteira comum; isso sempre causou muito conflito, essas inspeções frequentemente terminavam no pôr do sol ou sem acordo. A fronteira para dentro do lago era mais fácil, porque os Uros não estavam presentes. As comunidades nos diziam onde era e copiávamos aquilo.

As autoridades dos Uros declinaram de participar na demarcação dos territórios costumeiros das populações ribeirinhas porque se recusavam a reconhecer a legitimidade desse processo, ou da Reserva como mediadora.

Dessa maneira, tanto os Uros quanto as comunidades ribeirinhas formalizaram suas demandas em contextos em que a outra parte não estava presente, apropriando-se assim de toda a área por omissão, ao invés de negociarem uma fronteira comum. Não tendo encontrado qualquer resistência na época de sua formalização, ambas as partes passaram a ver suas reivindicações como incontestes e agora consideram toda a área como indubitavelmente sua. Essa precisa definição de territórios, no entanto, foi apenas um passo em direção à emergência de territórios costumeiros sem ambiguidades. Outro processo desempenhou um papel igualmente crucial: o fechamento gradual desses territórios ao seu uso por estranhos. 


\section{O fechamento de territórios}

Inicialmente, a redefinição conceitual de territórios aquáticos como precisamente delimitados não se refletiu, contudo, em uma mudança substancial das práticas nos juncais. Como foi mencionado antes, arranjos costumeiros foram caracterizados por um nível considerável de flexibilidade, ambiguidade, permeabilidade de fronteiras e trocas recíprocas. Por algum tempo, Uros e populações ribeirinhas, caçadores e cortadores de juncos continuaram a se mover para dentro e para fora do território um do outro sem grande impedimento. No entanto, como nos Andes o usufruto factual de territórios e de seus recursos é um importante elemento na maneira como os direitos territoriais são afirmados, a escalada do conflito fez com que, para ambas as partes, o impedimento da presença do outro na área contestada adquirisse cada vez mais importância política. Em decorrência, o conflito também resultou no fechamento e na exclusividade gradual dos territórios. Essa transformação pode ser ilustrada com o exemplo da caça de pássaros pelos Uros.

Devido a flutuações nos níveis do lago, os territórios aquáticos das comunidades ribeirinhas são cruciais para os caçadores Uros. Os pássaros concentram-se em volta de juncos densos. Como o lago no território dos Uros é mais fundo, durante a estação chuvosa do ano os juncos ficam submersos nessa área, ${ }^{7}$ e os caçadores seguem os pássaros que afluem para as partes mais rasas, perto da costa. Tanto os caçadores quanto as autoridades do Comitê de Conservação declararam repetidamente que isso nunca foi um problema antes: como os Uros caçam e as populações ribeirinhas cortam juncos, não havia concorrência pelos recursos. As relações, pelo contrário, tendiam a ser relativamente boas: muitos caçadores Uros estabeleceram relações de compadrio com ribeirinhos, aprenderam quechua e compartilhavam parte de suas caças com os cortadores de juncos que encontraram. Essa relação relativamente amigável sofreu, no entanto, profundas mudanças depois que emergiu o conflito, como ilustra Valentin, um caçador Uro:

Antes, os ribeirinhos eram sempre agradáveis comigo quando eu ia caçar em suas áreas, se eu os encontrasse normalmente daria a eles uma ou duas chok'as [carquejas]. Só algumas vezes, quando eu já tinha caçado muitos pássaros, pediam que eu me retirasse. Mas agora eles vêm e te perseguem, te pegam e confiscam tudo que é teu, tua espingarda. Isso nunca aconteceu comigo, mas já aconteceu com outros. Eles saem para patrulhar com quatro, cinco pessoas. Um tempinho atrás eu encontrei pessoas da beira do lago. Eles perguntaram de onde eu era. Como eles fazem mais rebuliço com pessoas dos Uros e de Chulluni, eu disse que era de K'api. ${ }^{8}$ Eles responderam: "se você é de K'api tudo bem, nós só queremos pegar gente dos Uros". 
Figura 4 - Pescando em balsa de juncos

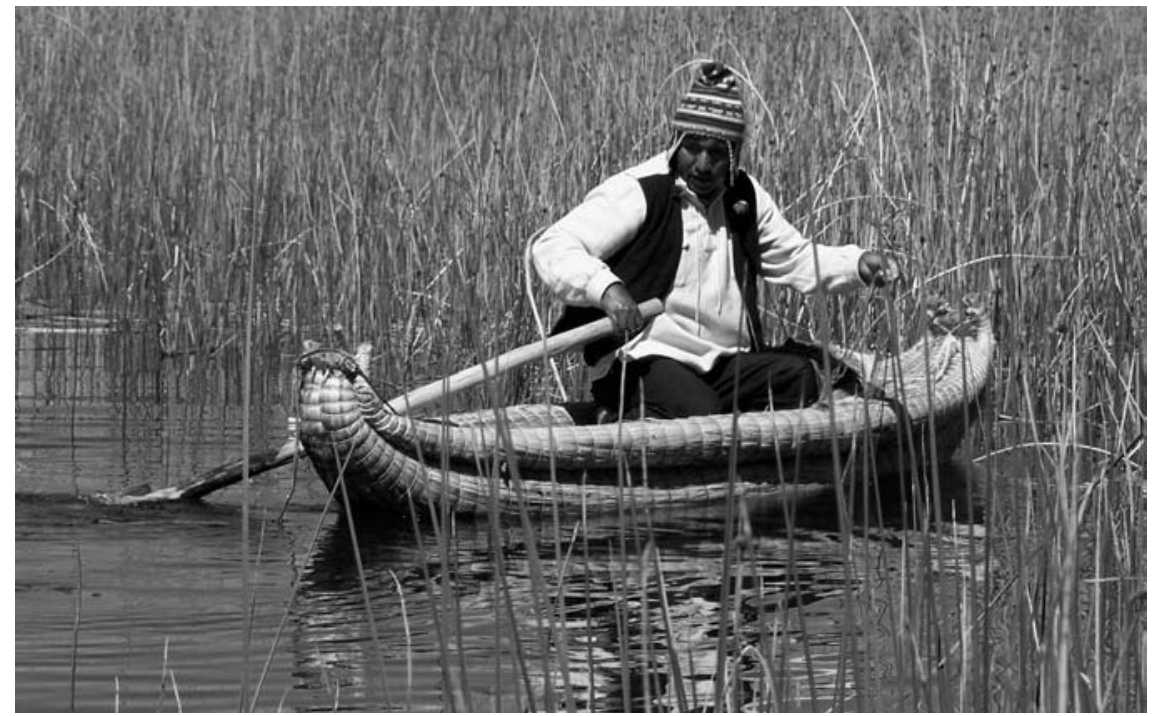

A primeira vez em que um Uro fez menção de um caso desses de perseguição a caçadores foi em março de 2005, sintomaticamente pouco mais de um mês depois de um guarda florestal da Reserva ter sido feito refém por um dia pelos habitantes das ilhas flutuantes. Um ano depois, rumores de guardas florestais comunitários caçando Uros tinham se tornado numerosos. Autoridades dos Comitês de Conservação reconheceram que havia uma intenção deliberada nisso, como ilustrava Nestor, presidente do Comitê de Collana:

Esse mês fizemos uma patrulha especial com os nossos guardas florestais comunitários e com a Reserva. Não foi anunciada, para que pudéssemos capturar caçadores e pescadores Uros. Fomos até a fronteira mais distante, o Balsero Mayo. Mas naquele dia, não tinha ninguém lá.

Essas táticas receberam fortes estímulos dos funcionários da Reserva. Por exemplo, depois de diversos presidentes de Comitês de Conservação reclamarem, durante sua reunião mensal de abril de 2006, que os guardas florestais comunitários estavam sofrendo ameaças de caçadores Uros, um dos guardas da Reserva respondeu desta forma:

Precisamos que vocês façam mais rondas. Se forem ameaçados, saiam com mais gente. Já pedimos a vocês que nomeiem mais guardas florestais, nós queremos 
muito mais guardas. [...] Quando formos patrulhar as áreas de vocês, vocês precisam nos acompanhar com 50 pessoas; nós viremos com a polícia, assim vocês vão ter o território de vocês respeitado. Esta é a forma de nos fazermos presentes, de recuperar dos Uros, aos poucos, a nossa jurisdição.

Naquela altura, a Reserva já treinara mais de 100 guardas florestais comunitários. As autoridades de diversos Comitês de Conservação alegavam que, como patrulhavam com mais frequência, o número de Uros entrando em seu território diminuíra consideravelmente. As patrulhas conjuntas de guardas da Reserva e da comunidade tinham como objetivo o estabelecimento de um clima de medo que desencorajasse os Uros a entrar na área contestada. Num irônico revés de sorte, os caçadores Uros tinham se tornado a presa. Cada vez mais tomavam precauções, entrando nos territórios das populações ribeirinhas no fim da tarde, quando os últimos cortadores de juncos tinham regressado a terra, e evitando por completo as áreas reivindicadas pelas comunidades mais antagônicas. O fechamento territorial resultante desses processos impediu os Uros de efetivamente imporem suas reivindicações por meio do usufruto da área contestada.

Assim, nos juncais da Baía de Puno, o envolvimento entre populações indígenas e o Estado resultou na transformação de territórios relativamente flexíveis, vagamente definidos e permeáveis em territórios mais fixos, claramente delimitados e exclusivos. Estas transformações nas práticas territoriais não tiveram, contudo, apenas consequências nas relações entre os Uros e o mundo exterior. Como revela a introdução, elas também tiveram efeitos profundos no âmbito da comunidade, em especial por meio da mobilização de técnicas de fixação com o objetivo de controlar a contínua fusão e cisão de ilhas flutuantes. Como resultado, a interação dinâmica entre flexibilidade e fixação que caracterizava o choque entre práticas territoriais indígenas e estatais nos juncais encontrou expressão também no nível comunitário. É com uma análise desse processo que terminará este artigo.

\section{A organização de ilhas flutuantes entre fixação e flexibilidade}

Como foi discutido na introdução, os esforços de alguns Uros em concentrar os benefícios advindos do turismo levaram a uma proliferação crescente de ilhas cada vez menores no rio Huili. Em resposta ao crescimento das desigualdades econômicas decorrentes desse processo, habitantes das ilhas com pequena participação no turismo começaram a pressionar as autoridades dos Uros por medidas voltadas para uma distribuição mais ampla de bene- 
fícios. Em especial, demandavam a fusão de ilhas em unidades maiores, a proibição da separação de ilhas e o estabelecimento de um sistema rotativo de barcos de turismo, fazendo com que visitassem todas as ilhas. A maioria das autoridades dos Uros - tanto dentro do município como entre as ilhas - era favorável a esse plano por uma razão adicional: a proliferação de ilhas flutuantes tornava a sua administração cada vez mais difícil.

Duas tentativas anteriores ao que se tratava geralmente como a "organização" (organización) de ilhas foram feitas em 2003 e 2004. Embora em ambos os casos a fusão de ilhas em unidades maiores tenha sido inicialmente um sucesso, uma vez que a pressão política arrefeceu, os Uros com laços mais privilegiados com guias turísticos logo se separaram outra vez. Depois de cada tentativa fracassada, o número de ilhas aumentou. Por exemplo, em abril de 2004 havia 12 ilhas flutuantes no rio Huili, com uma média de 13 famílias em cada uma. Estas se fundiram em sete unidades maiores, a maior parte das quais com mais de 20 famílias. Até o início de 2005, no entanto, elas tinham se separado novamente em 20 ilhas, muitas das quais com seis famílias ou menos.

Como resposta a essa desintegração, muitos Uros buscaram no uso de regulação formal e nas técnicas de fixação das práticas territoriais uma solução para fazer da fusão das ilhas um sucesso mais permanente. Quando as autoridades Uros iniciaram a organização de ilhas pela terceira vez, em fevereiro de 2005, houve uma demanda considerável, por parte da população das ilhas, por medidas mais rigorosas. A despeito da forte oposição de ilhas menores, a maioria tomou as seguintes decisões: uma nova lei interna proibiria a separação das ilhas; cada ilha receberia a sua resolução - equivalente a uma licença - citando o número de famílias habitantes, e qualquer mudança desse número teria que ser aprovada pelo conselho diretivo da ilha; um mínimo de 12 famílias por ilha foi estabelecido, mais tarde reduzido a oito. Ilhas que não conseguissem obedecer a estas regras seriam punidas com a proibição de receber turistas.

Estas medidas implicavam uma transposição parcial da abordagem mais fixa de territorialidade com a qual os Uros e suas autoridades tinham se familiarizado desde sua campanha para a Reserva Comunal. O sistema de licenças acabou por trazer de volta, ironicamente, o plano da Reserva Nacional que os Uros tão firmemente tinham rejeitado em 2001. Em seu conflito com a Reserva Nacional, o uso de uma abordagem fixadora da territorialidade ocasionara efeitos positivos importantes para eles, incluindo o aumento da legitimidade de suas reivindicações territoriais aos olhos de outros atores estatais, a consolidação de um apoio político mais amplo e a conquista de um espaço relativamente autônomo para além da influência da Reserva. Tais efeitos positivos tornaram a aplicação dessa abordagem fixadora 
Figura 5 - Reunião de autoridades

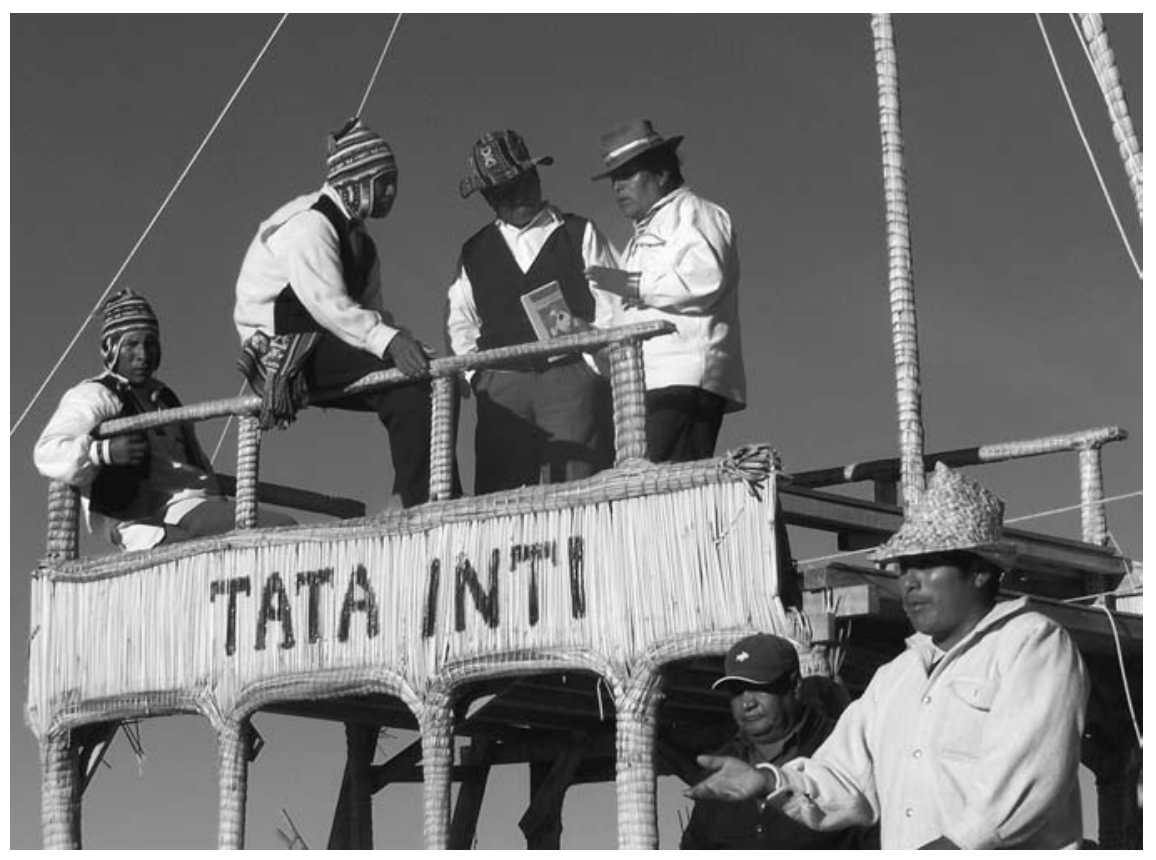

atraente para a solução de problemas sociais internos nas ilhas flutuantes. Logicamente, as medidas que as autoridades Uros introduziram não eram cópias diretas de regras estatais existentes: eram construções criativas a partir de inumeráveis elementos disponíveis, moldados na imagem que eles tinham do que significa controlar práticas territoriais.

Depois de diversas reuniões de autoridades, muita discussão e progressiva pressão nas ilhas menores, foi estabelecido o prazo de 30 de abril para que todas as ilhas chegassem a um mínimo de oito famílias, ou penalidades seriam postas em prática. O encontro de autoridades agendado para o dia 30 de abril começou em tom esperançoso. Como resultado da pressão política, dois conjuntos de ilhas com quatro a seis famílias tinham se fundido. Duas outras ilhas tinham conseguido aumentar seus números para oito famílias. Cinco das seis ilhas remanescentes com menos de oito famílias prometeram obedecer no período de uma semana. Então, de repente, a reunião virou do avesso quando o presidente da ilha de Totora anunciou a divisão de sua ilha. Uma discussão acalorada se seguiu entre as duas facções de Totora que iriam se separar. Pouco depois, o presidente de Tribuna - a maior e mais antiga ilha do rio Huili — informou que sua ilha decidira também se separar. A reunião terminou ao anoitecer, em 
meio ao caos, com participantes gritando por sanções e conflitos sendo travados abertamente. Sendo a finalização da união das ilhas o ponto central da pauta, sua desintegração se impôs à reunião. Quando deixei o campo, seis semanas depois, já existiam 30 ilhas. Desde então, tentativas de organização das ilhas em unidades maiores foram inteiramente abandonadas. No momento em que escrevo, em 2011, existem mais de 60 ilhas.

Em todas as tentativas de organização das ilhas havia tanto forças centrífugas quanto centrípetas em operação. As primeiras relacionavam-se, principalmente, aos interesses das ilhas pequenas, especializadas em turismo, enquanto as últimas associavam-se às autoridades políticas e a uma maioria de habitantes de ilhas marginalizados do turismo. Há, no entanto, uma diferença nítida entre a organização das ilhas em 2005 e os esforços anteriores. Em 2003 e 2004, quando a fusão das ilhas foi realizada sem o uso das técnicas formais voltadas para a fixação permanente de práticas territoriais, ela foi conseguida - mesmo que apenas temporariamente. Quando tais medidas foram introduzidas na terceira tentativa, constatou-se a impossibilidade de se completar a organização de ilhas. Portanto, a abordagem fixadora terminou por provocar o efeito oposto: a prática territorial tornou-se ainda mais volátil e incontrolável, e o número de ilhas expandiu-se significativamente. Alguns moradores das ilhas pareciam estar cientes dessa relação. Por exemplo, quando o encontro de 30 de abril saiu do controle, um de seus participantes disse: "Será que vocês não veem que quanto mais tentamos organizar as ilhas mais elas se separam? Quanto mais forçarmos as pessoas a viverem juntas mais conflito haverá".

Por que a organização de ilhas provou ser ainda mais difícil de ser alcançada quando a regulação e a abordagem fixadora da territorialidade foram mobilizadas para fazê-la valer? Fixar o caráter flexível das ilhas flutuantes teria um impacto que iria muito além de meramente afetar os interesses econômicos de ilhas bem-sucedidas no turismo. Também tocaria diretamente num dos princípios básicos da vida social dos Uros. Como foi discutido antes, a capacidade de se mover de um lugar para o outro, mudar de ilha ou fundar uma nova está no centro das estratégias flexíveis com as quais os Uros historicamente confrontaram os diversos desafios ambientais, sociais, políticos e econômicos com que se depararam — tanto em nível individual como coletivo. Isto explica por que os habitantes das ilhas acataram a sua organização em 2003 e 2004, quando tinha um caráter menos compulsório, mas se recusaram a fazer o mesmo quando a regulação foi introduzida com o objetivo de fixar esse processo de forma mais permanente. Embora muitos Uros tenham passado a ver a proliferação de ilhas e as desigualdades dela resultantes como um problema, poucos pareciam dispostos a abrir mão de 
sua prerrogativa de mobilidade e flexibilidade. Consequentemente, suas autoridades tiveram tão pouco sucesso quanto a Reserva em disciplinar e fixar a contínua fusão e separação de ilhas flutuantes.

\section{Conclusões}

As práticas territoriais de populações indígenas cada vez mais se moldam na interseção de suas próprias abordagens costumeiras flexíveis e a orientação pronunciadamente mais fixa introduzida pelas instituições estatais com as quais interagem. De forma a entender essas práticas em seu contexto mais amplo, é de especial importância concentrar a análise nas duas dimensões interrelacionadas exploradas neste artigo. Estas consistem, primeiro, na tensão-chave entre flexibilidade e fixação e, segundo, na interação dinâmica entre práticas territoriais no nível da comunidade e aquelas que medeiam relações com o mundo exterior. Como revelou o caso dos Uros, essas práticas territoriais internas e externas apresentam diferenças significativas nas maneiras pelas quais a tensão entre flexibilidade e fixação se desenrola. No entanto, elas também dão forma uma à outra mutuamente.

A flexibilidade de práticas territoriais nas ilhas flutuantes foi espelhada pelos arranjos territoriais igualmente flexíveis que os Uros estabeleceram com as populações Aymara e Quechua ribeirinhas. Seu progressivo envolvimento com a Reserva, contudo, resultou na emergência de tensões entre essas abordagens flexíveis e a orientação pronunciadamente fixa da territorialidade, própria da visão estatal. Paradoxalmente, o ponto de vista altamente flexível da territorialidade dos Uros contribuiu para a facilidade com que eles se apropriaram de técnicas de fixação. Em decorrência, as práticas territoriais que mediavam relações entre os Uros e as comunidades ribeirinhas passaram por profundas mudanças.

No lapso de poucos anos, territórios relativamente flexíveis, vagamente definidos e permeáveis, transformaram-se em territórios mais fixos, demarcados de forma clara e exclusivos. Essas transformações, contudo, não se limitaram às relações sociais externas. Quando as autoridades Uros começaram a usar uma abordagem mais fixa da territorialidade de modo a regular as relações internas nas ilhas flutuantes, isto resultou na reprodução de tensões similares entre flexibilidade e fixação no nível comunitário. O desfecho neste caso foi, contudo, bastante diferente. Esforços da população das ilhas para preservar sua prerrogativa de mobilidade - um elemento central em suas respostas aos desafios climáticos, sociais e econômicos resultaram em uma volatilidade maior de suas práticas territoriais. 
No restante das conclusões, concentrar-me-ei nas implicações teóricas adicionais dos processos analisados neste artigo para as relações entre populações indígenas e o Estado. Em primeiro lugar, o envolvimento do Estado com territórios e práticas costumeiros produz mudanças expressivas nestes últimos. A aceitação, por atores estatais, da existência de arranjos e territórios costumeiros não necessariamente implica uma ratificação de práticas preexistentes. Pelo contrário, no presente caso, a codificação pela Reserva de territórios e práticas costumeiros resultou em transformações consideráveis nos arranjos locais: formar uma argumentação admissível da existência de territórios costumeiros da população ribeirinha implicava, de fato, construir esses territórios.

No processo, a Reserva passou por cima de arranjos costumeiros existentes, de modo a criar o tipo de regras e territórios "costumeiros" que fossem de uso mais estratégico para ela mesma e para seus aliados ribeirinhos. Consequentemente, a elaboração do mapa de Zonas de Uso Ancestral alterou de maneira considerável o tamanho e a forma dos territórios aquáticos. A Reserva também transformou a natureza dos arranjos locais ao homogeneizar uma mistura de regras de acesso privadas e coletivas em um único formato de territórios coletivos. Outra alteração consistiu na mudança na distribuição do acesso aos juncais para os aliados e os oponentes da Reserva. Por fim, esses processos - em conjunto com a definição e o fechamento de territórios — reduziram significativamente ambiguidades, facilitando com isso o controle territorial.

Os incentivos que grupos indígenas recebem para reivindicar seus territórios costumeiros são ao mesmo tempo investidas em direção à fixação desses territórios. Isto significa que, em um nível conceitual, eles enfrentam um dilema crucial: obter o reconhecimento formal de seus territórios costumeiros também resulta em uma gradual supressão da própria natureza desses territórios. De fato, poder-se-ia argumentar que, como os arranjos costumeiros costumam ser flexíveis e se adaptar continuamente à realidade local em transformação, sua codificação em um corpo fixo de regras implica, por si mesma, uma profunda transformação, o que denota ser uma homogeneização e uma hierarquização de regras muito diversas e dispersas, aplicadas de forma diferente de acordo com o contexto. Por sua vez, plantam-se assim as sementes do futuro conflito, já que os elementos fixos se tornam objeto de contestação por pessoas envolvidas numa prática em mudança contínua (cf. Almeida \& Franco 2000). A perspectiva é a de um jogo interminável.

Uma segunda implicação teórica é a de que os conflitos territoriais, como o travado na Baía de Puno, resultam em uma convergência entre práticas territoriais estatais e indígenas. Embora a Reserva não tenha conseguido tomar o controle do território dos Uros, ela atingiu seus objetivos em outros domínios. Compeliu os Uros e as populações ribeirinhas a jogarem de acordo com as regras 
do Estado, priorizando formas de territorialidade fixas e delimitadas. É claro que não foi apenas o Estado que se beneficiou desse jogo. O uso de categorias fixas e exclusivas propostas pelo Estado - fossem elas originadas na lei formal ou na apropriação seletiva do Estado dos arranjos costumeiros — trouxe aos grupos indígenas de ambos os lados do conflito um benefício importante: aumentou o tamanho e o peso político de suas reivindicações territoriais. Este não foi, entretanto, um processo unidirecional. Embora os Uros ainda não tenham conseguido o reconhecimento de suas reivindicações, eles foram bem-sucedidos em forçar o Estado a jogar de acordo com as regras dos indígenas, nas quais arranjos costumeiros, propriedade coletiva e tempo de usufruto desempenham um papel central. Assim, grupos indígenas e o Estado forçaram um ao outro a atender, no conflito, às regras do jogo de cada um deles.

Os Uros, as comunidades ribeirinhas e a Reserva estavam inicialmente envolvidos em formas de territorialização muito distintas. Como resultado do conflito, estas convergiram para um processo comum de territorialização, a partir do qual vieram à tona uma linguagem comum e regras compartilhadas. Este fato possibilitou que todas as partes se envolvessem e se confrontassem em torno da mesma área, no âmbito de uma arena política compartilhada. A despeito de seus muitos desentendimentos, os Uros, as comunidades ribeirinhas e a Reserva pareciam concordar com os termos do debate: direitos territoriais e sua antiguidade. Por meio desta convergência gradual de concepções territoriais, o conflito construiu pontes que tornaram possível o envolvimento de atores do Estado e indígenas.

No nível da comunidade, no entanto, ao invés de construir pontes, essas inovações das práticas territoriais resultaram na emergência de novas divisões entre os Uros. Elas reproduziram as mesmas tensões entre flexibilidade e fixação que tinham sido mediadas, em parte, na sua relação com a Reserva por meio da articulação de abordagens indígenas e estatais. Em decorrência disto, as práticas territoriais dos Uros começaram a se desdobrar nessa interação dinâmica entre flexibilidade e fixação, e suas vidas sociais continuaram a se desenvolver num fluxo permanente entre tendências centrípetas e centrífugas, entre a união e a divisão de ilhas.

Recebido em 10 de setembro de 2011

Aprovado em 13 de outubro de 2011

Tradução de Fernanda Guimarães

Michael Kent é professor da Universidade de Manchester. E-mail: <Michael. Kent@manchester.ac.uk> 


\section{Notas}

1 Os dados nos quais este artigo se baseia foram coletados ao longo de quatro períodos de trabalho de campo que duraram de dois a quatro meses, entre 2003 e 2006. A pesquisa foi financiada pela Escola de Ciências Sociais da Universidade de Manchester e pelo Royal Anthropological Institute. Sou particularmente grato a Penny Harvey, John Gledhill, Peter Wade, Olivia Harris (falecida), Karen Sykes e Andrew Canessa por suas contribuições valiosas à reflexão desenvolvida neste artigo. Desejo também agradecer a Karl Hennermann por sua perícia na elaboração dos dois mapas.

2 Se esta reivindicação é legítima ou não, sujeita-se a considerável debate em Puno, envolvendo argumentos sociais, culturais, linguísticos, etno-históricos e mesmo genéticos (Kent 2011). Atualmente há apenas três outros grupos reconhecidos como Uros, todos situados na Bolívia, com população total de aproximadamente 2.500 pessoas.

3 Esses arranjos foram desfeitos como resultado da criação da Reserva, cujas políticas eram voltadas para conceder acesso direto à população ribeirinha sem a mediação dos Uros e a negar por completo o acesso a grupos que vivessem fora da Baía de Puno (Kent 2006).

4 Para a história da criação da Reserva, ver Orlove (1991). Relações entre a Reserva e as populações locais foram tensas desde o começo. Durante a fase de planejamento, a oposição inicial conseguiu excluir substanciosas áreas de juncos da Reserva. No menor dos dois setores da Reserva - a Baía de Ramis, no canto nordeste do Lago Titicaca - as populações locais conseguiram impedir sua administração efetiva. Na primeira década de sua existência, a Reserva foi administrada com fundos limitados e estabeleceu uma fraca presença na Baía de Puno. Entre 1990 e 1996, sua administração ficou abandonada por completo.

${ }^{5}$ Decreto Supremo 009-2006 AG. Este decreto reconhece os direitos de posse, uso e usufruto. Não garante, contudo, direitos de propriedade.

${ }^{6}$ Área de Recreação foi o nome dado, no zoneamento provisório da Reserva, à área em que o turismo era permitido.

7 Períodos de seca são uma exceção, já que durante esse tempo os juncos não ficam submersos.

${ }^{8}$ Ver mapa 1. Com o termo "Uros", as populações ribeirinhas e os funcionários da Reserva geralmente se referem apenas a (habitantes das) ilhas flutuantes do rio Huili. Habitantes de Chulluni são chamados de Chullunis e os Uros das ilhas flutuantes localizadas mais para dentro dos juncais são chamados de K'apiños. O foco inicial das patrulhas sobre os habitantes das ilhas flutuantes do rio Huili é compreensível, já que, com poucas exceções, populações de Chulluni e K'api tinham pouco envolvimento na luta por autonomia territorial. 


\section{Referências bibliográficas}

ALBERT, Bruce. 2004. "Territorialidad, etnopolítica y desarrollo: a propósito del movimiento indígena en la Amazonía brasileña". In: A. Surrallés \& P. García Hierro (eds.), Tierra adentro; territorio indígena y percepción del entorno. Copenhague: IWGIA. pp. 221-258.

ALLIES, Paul. 1980. L'invention du territoire. Grenoble: Presses Universitaires de Grenoble.

ALmeidA, Mauro W. Barbosa de \& FRANCO, Mariana C. Pantoja. 2000. "A justiça local: caça e estradas de seringa na Reserva Extrativista do Alto Juruá". XXII Reunião Brasileira de Antropologia, Brasília.

ALONSO, Ana Maria. 1994. "The politics of space, time, and substance: state formation, nationalism and ethnicity". Annual Review of Anthropology, 23:379-405.

AUGÉ, Marc.1992. Non-lieux: introduction à une anthropologie de la surmodernité. Paris: Seuil.

BOURDIEU, Pierre. 1980. "Lidentité et la représentation; éléments pour une réflexion critique sur l'idée de région". Actes de la Recherche en Sciences Sociales, 35:63-72.

BOUYSSE-CASSAGNE, Thérèse \& HARRIS, Olivia. 1987. "Pacha: en torno al pensamiento Aymara". In: T. Bouysse-Cassagne; V. Cereceda; O. Harris $\&$ T. Platt (eds.), Tres reflexiones sobre el pensamiento andino. La Paz: Hisbol.

BRUNET, Roger. 1986. "L'espace, règles du jeu". In: F. Auriac \& R. Brunet (eds.), Espaces, jeux et enjeux. Paris: Fondation Diderot/Fayard. pp. 297-316.

BRYSK, Alison. 2000. From tribal village to global village: indian rights and inter- national relations in Latin America. Stanford: Stanford University Press. CASIMIR, Michael J. \& RAO, Aparna. 1992. Mobility and territoriality: social and spatial boundaries among foragers, fishers, pastoralists, and peripatetics. New York: Berg.

CERTEAU, Michel de. 1980. L'Invention $d u$ quotidien. 2 vols. Paris: Union Générale D'Éditions.

CREAMER, Howard. 1988. "Aboriginality in New South Wales: beyond the images of cultureless outcasts". In: J. Beckett (ed.), Past \& present: the construction of aboriginality. Victoria: Australian Institute of Aboriginal Studies. pp. 131-146.

DELEUZE, Gilles \& GUATTARI, Felix. 1992. A thousand Plateaus. Capitalism and schizophrenia. London, New York: Continuum.

FERGUSON, James \& GUPTA, Akhil. 2005. "Spatializing states: toward an ethnography of neoliberal governmentality". In: J. X. Inda (ed.), Anthropologies of modernity: Foucault, governmentality, and life politics. Malden, MA: Blackwell Pub.

GALLOIS, Dominique Tilkin. 1998. "Brazil: the case of the Waiãpi". In: A. Gray; A. Parellada \& H. Newing (eds.), From principles to practice: indigenous peoples and biodiversity conservation in Latin America. Copenhagen: IWGIA.

GARCÍA HIERRO, Pedro \& SURRALlÉS, Alexandre. 2004. "Introducción". In: . (eds.), Tierra adentro; territorio indígena y percepción del entorno. Copenhague: IWGIA. pp. 9-24.

GEERTZ, Clifford. 1959. "Form and variation in balinese village structure". American Anthropologist, 61:991-1012. 
GREEN, Sarah F. 2005. Notes from the Balkans: relocating marginality and ambiguity on the Greek-Albanian border. Princeton, N.J.: Princeton University Press.

GUPTA, Akhil \& FERGUSON, James. 1992.

"Beyond 'culture': space, identity, and the politics of difference". Cultural Anthropology, 7(1):6-23.

. 1997. "Culture, power, place: ethnography at the end of an era". In: (eds.), Culture, power, place: explorations in critical anthropology. Durham, London: Duke University Press. pp. 1-32.

HIRSCH, Eric. 1995. "Landscape: between place and space". In: \& M. O'Hanlon (eds.), The anthropology of landscape; perspectives on place and space. Oxford: Clarendon Press. pp. 1-30.

KENT, Michael. 2006. "From reeds to tourism: the transformation of a territorial conflict in the Titicaca National Reserve". Current Issues in Tourism, 9(1):86-103.

. 2008. "The making of customary territories: social change at the intersection of state and indigenous territorial politics on Lake Titicaca, Peru". Journal of Latin American and Caribbean Anthropology, 14(2):283-310.

. 2009. "How to make the State listen: indigenous violence, State fears and everyday politics in Peru". Etnofoor, 21(2):11-34.

2011. "A importância de ser Uros: movimentos indígenas, políticas de identidade e pesquisa genética nos Andes Peruanos". Horizontes Antropoloìgicos, 35:297-324.

LACOSTE, Yves. 1986. "Géographie et géopolitique". In: F. Auriac \& R. Brunet (eds.), Espaces, jeux et enjeux. Paris: Fondation Diderot/Fayard. pp. 283-296.

LEHMANN, David. 1982. Ecology and exchange in the Andes. Cambridge; New York: Cambridge University Press.
LEVIEIL, Dominque P. \& ORLOVE, Benjamin S. 1990. "Local control of aquatic resources: community and ecology in Lake Titicaca, Peru". American Anthropologist, 92(2):362-382.

LIMA, Antonio Carlos de Souza. 1995. Um grande cerco de paz: poder tutelar, indianidade e formação do Estado no Brasil. Petrópolis: Vozes.

MACKENZIE, John M. 1990. Imperialism and the natural world. Manchester, New York: Manchester University Press.

MALLKI, Liisa H. 1997. "National geographic: the rooting of peoples and the territorialization of national identity among scholars and refugees". In: A. Gupta \& J. Ferguson (eds.), Culture, power, place: explorations in critical anthropology. Durham, London: Duke University Press. pp. 52-74.

MURRA, John V. 1975. Formaciones económicas y políticas del mundo andino. Lima: Fondo Editorial Pontificia Universidad Católica del Perú/ Instituto de Estudios Peruanos IEP.

NASH, Roderick. 1970. "The american invention of national park". American Quarterly, 22(3):726-735.

OLIVEIRA, João Pacheco de. 1998. “Uma etnologia dos 'índios misturados'? Situação colonial, territorialização e fluxos culturais". Mana. Estudos de Antropologia Social, 4(1):47-77.

ORLOVE, Benjamin S. 1991. "Mapping reeds and reading maps: the politics of representation in Lake Titicaca". American Ethnologist, 18(1):3-38. .2002. Lines in the water: nature and culture at Lake Titicaca. Berkeley: University of California Press.

PELUSO, Nancy Lee. 2005. "Whose woods are these? Counter-mapping forest territories in Kalimantan, Indonesia". In: M. Edelman \& A. Haugerud (eds.), The anthropology of development and 
globalization: from classical political economy to contemporary neoliberalism. Malden, MA: Blackwell Pub.

RAFFESTIN, Claude. 1986. “Ecogénèse territoriale et territorialité". In: F. Auriac \& R. Brunet (eds.), Espaces, jeux et enjeux. Paris: Fondation Diderot/Fayard. pp. 173-186.

RAMOS, Alcida R. 1998. Indigenism: ethnic politics in Brazil. Madison: University of Wisconsin Press.

RAPPAPORT, Joanne. 1985. "History, myth, and the dynamics of territorial maintenance in Tierradentro, Colombia". American Ethnologist, 12(1):27-45.

RODMAN, M. C. 1992. "Empowering place: multilocality and multivocality". American Anthropologist, 94:640-656.

SCOTT, James C. 1998. Seeing like a state: how certain schemes to improve the human condition have failed. New Haven: Yale University Press.

SIEDER, Rachel. 2002. Multiculturalism in Latin America: indigenous rights, diversity, and democracy. Houndmills, Basingstoke; Hampshire, New York: Palgrave Macmillan.

SPENCE, Mark David. 1999. Dispossessing the wilderness: indian removal and the making of the national parks. New York: Oxford University Press.

VAN COTT, Donna Lee. 1994. Indigenous peoples and democracy in Latin America. New York: St. Martin's Press.

VANDERGEEST, Peter \& PELUSO, Nancy Lee. 1995. "Territorialization and State power in Thailand". Theory and Society, 24(3):385-426.

VIESNER, Frédéric. 2002. "Dynamique territoriales des Aborigènes Pitjantjatjara (Australie-Méridionale)". Études Rurales, 163-164:267-282.

WACHTEL, Nathan. 1990. Le retour des ancêtres: les indiens Urus de Bolivie, XXe-XVIe siècle; essai d'histoire régressive. Paris: Éditions Gallimard. 


\section{Resumo}

Em sua busca pelo reconhecimento de seus territórios costumeiros, as populações indígenas das Américas têm progressivamente lançado mão de técnicas modernas para a definição precisa de territórios. Isto resultou em tensões entre suas práticas muitas vezes altamente flexíveis e as modalidades mais fixas de territorialidade produzidas por tais técnicas. O objetivo deste artigo é explorar essas tensões e suas consequências sociais por meio da análise das práticas territoriais dos Uros, um grupo indígena que habita ilhas flutuantes nos juncais do lago andino Titicaca. Tais práticas serão analisadas tanto no nível da comunidade quanto em suas relações conflitantes com as comunidades vizinhas na costa do lago e com uma área protegida administrada pelo Estado peruano. As práticas territoriais internas dos Uros revelam elevados níveis de mobilidade física e flexibilidade social, resultantes do constante fundir e separar das ilhas artificiais de junco. No entanto, seu envolvimento com o Estado e suas práticas territoriais têm resultado em profundas transformações em seus arranjos com as comunidades ribeirinhas. Em especial, redundou numa transformação dos territórios flexíveis, vagamente definidos e compartilhados, em territórios fixos, claramente definidos e exclusivos. Por fim, analisarei conflitos que emergiram entre os Uros quando seus líderes tentaram aplicar mecanismos de fixação territorial, de forma a controlar a constante fusão e separação das ilhas flutuantes.

Palavras-chave Movimentos indígenas, Práticas territoriais, Estado, os Andes.

\section{Abstract}

In their quest for the recognition of their customary territories, indigenous populations of the Americas have increasingly made use of modern techniques for the precise definition of territories. This has resulted in tensions between their often highly flexible territorial practices and the more fixed modalities of territoriality produced through such techniques. The objective of this article is to explore such tensions and their social consequences by analysing the territorial practices of the Uros, an indigenous group living on floating islands in the reed beds of the Andean Lake Titicaca. It will analyse such practices both at the community level and in their conflictive relations with neighbouring lakeshore communities and a protected area administered by the Peruvian state. The Uros' internal territorial practices reveal high levels of physical mobility and social flexibility, resulting from their continuous merging and scission of the artificial reed islands. However, their engagement with the state and its territorial practices has resulted in profound transformations to their arrangements with the lakeshore communities. In particular, it has resulted in a transformation of flexible, vaguely defined and shared territories into fixed, clearly defined and exclusive territories. Finally, I will analyse conflicts that emerged among the Uros when their leaders tried to apply mechanisms for territorial fixation in order to control the continuous merging and scission of floating islands.

Key words Indigenous movements; territorial practices; the state; the Andes. 